\title{
Eltemetett humuszos talajrétegek előfordulása a Szigetközben és környékén
}

\author{
SZÜCS MIHÁLY és SZÜCS MIHÁLYNÉ
}

Nyugat-Magyarországi Egyetem, Mezőgazdaság- és Élelmiszertudományi Kar, Talajtani és Vízgazdálkodási Tanszék, Mosonmagyaróvár

A öntéstalajok felső, humuszos rétege alatt esetenként előforduló második, vagy további humuszos réteget, ha annak szervesanyag-tartalma meghaladja az 1\%-ot és mechanikai összetétele egy kategóriával agyagosabb a környező rétegeknél, eltemetett humuszos rétegnek nevezzük (BARANYI et al., 1987).

Eltemetett rétegeket legtöbbször hidromorf talajokban, vagy illuviális rétegekben figyelhetünk meg, ahol a levegőtlenség miatt a humusztartalom jól konzerválódik. A csernozjomok porózus rétegének humusza az eltemetődés és az utánpótlás megszünése után nem őrződne meg (GERASZIMOV, 1974).

Az ilyen réteg jelenlétének és tulajdonságainak több szempontból fontos jelentősége lehet. Ha a szántott réteg alatt nem nagy mélységben helyezkedik el, hozzájárulhat az adott talaj termékenységének javításához (Izsó, 1986; SzABOLCS, 1966). Előfordulhatnak kedvezőtlen hatások is. A Tisza magyarországi alsó szakasza mentén sok helyen jelen lévő többrétegü öntések eltemetett, erősen tömődött, szurokfekete altalajairól megállapították, hogy azok a gyökérfejlödés gátját képezhetik (IMRE, 1998).

A felszín alatt nem nagy mélységben elhelyezkedő, lebomlási folyamatoknak nagymértékben ellenálló szervesanyag-tartalommal rendelkező réteg kibányászva rekultivációs tevékenység (SEVÜREV et al., 1988), vagy parkosítás, kertépítés alapanyagát képezheti. Az üvegházi zöldség- és virágtermesztés rendszeresen jelentkező földcsere igényeinek kielégítésében is szerepet játszhat. Megfelelő körültekintésre itt is szükség van, mert előfordult, hogy az eltemetett réteg ólom- és nikkeltartalma nagyobb (EVSZEEV, 1991), mint a feltalajé.

A környezethez képest agyagosabb szövet és a mélyebb rétegek szokásos állapotához képest nagyobb szervesanyag-tartalom a víz és az oldott anyagok áramlását fékező hatása miatt a talajon áthatoló szennyeződések talajvízbe jutását csökkentheti (DUFFY et al., 1997). Előállhatnak olyan helyzetek, amikor ez a kiegészítő szüröréteg olyan környezetvédelmi értéket képvisel, hogy annak megtartása és védelme fontosabb lehet, mint egy kibányászás utáni hasznosítás.

Postai cím: SZÜCS MIHÁLY, NyME Mezőgazdaság- és Élelmiszertudományi Kar, Talajtani és Vízgazdálkodási Tanszék, 9200 Mosonmagyaróvár, Pozsonyi út 4. E-mail: szucsm@ mtk.nyme.hu 
Az eltemetett humuszos rétegek régebbi idők fotoszintetikus energiáját tárolják és örzik meg számunkra, a nemzeti vagyon részét képezik. Hasznosításukra, vagy fokozott védelmükre irányuló döntéseink megalapozása céljából a jelenleginél lényegesen többet kell megtudnunk róluk.

Folyóvizeink hordalékain kialakult jellemzően rétegezett öntéstalajaink gyakran tartalmaznak második humuszos réteget. Az adott talaj termékenységéhez való hozzájárulásuk mértékét gyakran csak gyakorlati megfigyelések, vagy a hasonló tulajdonságú feltalajok mérési adatai alapján tudjuk megbecsülni. Kevés a tényleges célirányos mérés. A talajok térképezése során általában a talajszelvények 20-40\%ának teljes megmintázásával számolhatunk (SZABOLCS, 1966), a felszín alatt található eltemetett rétegeket ezért nem minden esetben mintázzák meg, a laboratóriumba került nem feltalaj mintákon pedig nem minden paraméter vizsgálatát végzik el. Jellemző példa erre SzŰCS (1958) Maros menti allúviumok térképezéséről számot adó munkája, amelyben megállapítja, hogy a felszín közeli eltemetett humuszos rétegek termékenység növelö hatásúak, a hivatkozott rétegek növényi makrotápanyag vizsgálati adatai viszont hiányoznak, mivel azok nem voltak feltalajminták.

A Szigetköz-Mosoni-síkság kistájcsoport eltemetett humuszos rétegeinek kiterjedéséről és tulajdonságairól kevés ismerettel rendelkezünk. A térsége vonatkozó, talajtani jellemzéssel foglalkozó összefoglaló jellegü munkák (STEFANOVITS \& GÓCZÁN, 1962; VÁRALLYAY, 1992) ezt a jelenséget nem is tárgyalják. GÖCSEI (1979) természetföldrajzi jellegü tanulmányában tesz említést arról, hogy Kisbajcs és Vének környékén vannak ilyen foltok és, hogy nehéz azokat térképezni. Régebbi, kisebb területek részletesebb vizsgálatával foglalkozó munkákból (MIKLAY \& MOLNÁR, 1968; STEFANOVITS, 1943; ID. VÁRALLYAY, 1942) azonban kideríthető, hogy ilyen foltok másutt is előfordulnak. ID. VÁRALLYAY (1942) az általa kettős rétegezettségünek nevezett talajokat a legjobb tulajdonságúak közé sorolja. STEFANOVITS (1943) a bösi terület térképezése során szintén talált ilyen talajfoltokat, tehát azok a Csallóközben is előfordulnak. A Bős-Nagymarosi Vízlépcsőrendszer építése során végzett, a csak a Szigetközre kiterjedő részletesebb feltárások (MTA TAKI, 1986) alapján a szerzők ezen a kistájon a többrétegü öntések területi részarányát 3,6\%-ban állapítják meg.

Saját, 3 m-es mélységig terjedő fúrással kiterjesztett szelvényfeltárásaink során (SzÜCS, 1984; SzÜCS \& PALKOVITS, 1987) a GÖCSEI (1979) által jelzett kisbácsai térségen kívül még több helyen találtunk eltemetett humuszos szintet, esetenként két egymás alatti réteget is, eltérő tulajdonságokkal. Megállapítottuk, hogy területük a Szigetközben valószínúleg lényegesen több mint 3,6\% és a Mosoni-síkság kistájon is folytatódnak. Az akkori feladat nem tette lehetővé a területek pontos lehatárolását és a rétegek részletes vizsgálatát. Valószínü, hogy az eltemetett humuszos rétegek hatással vannak az adott talaj agrokémiai és vízgazdálkodási tulajdonságaira is. A területek lehatárolásának és a tulajdonságok pontos ismeretének hiányában azonban ezt a befolyást a Szigetközre vonatkozó feldolgozásainkban (SzÜCS, 1996, 1998; SzŰCS \& SZŰCSNÉ, 2000) eddig nem tudtuk figyelembe venni. Feltételezhető, hogy szerepük a térség talajtulajdonságainak meghatározásában lényegesen nagyobb, mint azt eddig gondoltuk. 


\section{Anyag és módszerek}

Összegyüjtöttük a Szigetközre vonatkozó és az eltemetett rétegek kimutatását is lehetővé tevő talajfeltárások adatait és azokat szükség szerint további helyszíni vizsgálatokkal egészítettük ki. A használható korábbi feltárások helyei a Szigetközben egyenetlenül oszlanak el, a Mosoni-síkságon pedig majdnem teljesen hiányoznak, ezért ott különösen sok kiegészítő vizsgálatra volt szükség. Végül több mint 2000 talajszelvény $150 \mathrm{~cm}$ mélységig terjedő vizsgálatának adatsorait tekintettük át. Ezen belül a saját, kiegészítő fúrásaink mélysége, ha azt kavicsréteg vagy talajvíz megjelenése nem akadályozta, maximálisan $350 \mathrm{~cm}$-ig terjedt. A feltárások helyeinek koordinátáit digitális állományba rögzítettük. Saját feltárásaink helyeit GPS segítségével azonosítottuk, a más forrásból származó korábbi feltárások koordinátáit talajtérképek és topográfiai térképek egybevetésével határoztuk meg. Mivel a korábbi talajtérképezési munkák során a feltárások helyeinek becslésére nem álltak rendelkezésre megfelelő eszközök, a régebbi szelvények helyének azonosítása során több száz métert is tévedhetünk, ez a hiba navigációs GPS használatával az új feltárásoknál 20 m-re mérséklődik.

A digitalizált pontokból térinformatikai szoftver segítségével, Thiessen poligonok képzése útján állítottuk elő a folthatárokat.

A különböző talajrétegek agrokémiai tulajdonságainak összehasonlításához a jellemzőnek ítélt pontokon és mélységekben mintákat gyüjtöttünk. A szántott réteg, a szántott réteg alatti még humuszos, de nem eltemetett réteg, a különböző mélységben megjelenő eltemetett humuszos rétegek, és a humuszmentes anyakőzet csoportokra osztott halmaz TVG vizsgálatát és értékelését végeztük el. A vizsgálatokat a Vas megyei NTSz végezte.

$\mathrm{Az}$ agrokémiai tulajdonságokat tenyészedény-kísérlet segítségével is ellenőriztük. A 6 literes edényekben tavaszi árpa jelzőnövénnyel beállított kísérlet kezelései az alábbiak voltak: 1. szántott talajréteg (feltalaj); 2. anyakőzet; 3. eltemetett humuszos réteg (Mosonmagyaróvár); 4. eltemetett humuszos réteg (Bezenye); 5. anyakőzet $+10 \%$ feltalaj; 6 . eltemetett humuszos réteg (Mosonmagyaróvár) $+10 \%$ feltalaj; 7. eltemetett humuszos réteg (Bezenye) $+10 \%$ feltalaj; 8 . anyakőzet + NPK mütrágya; 9. eltemetett humuszos réteg (Mosonmagyaróvár) + NPK-mütrágya; 10. eltemetett humuszos réteg (Bezenye) + NPK-mütrágya. Az NPK-mütrágya 16,5:16,5: 16,5 arányú technológiailag kevert mütrágya volt, amelyet 3 g/edény mennyiségben adtunk.

Az árpa levágása után a mütrágyázott kezelésekben a kísérletet tovább folytattuk görögszénával (téli időszak), majd tavasszal ismét tavaszi árpával.

$\mathrm{Az}$ ásványi nitrogén feltáródás ütemét a pórustér 60\%-áig nedvesített, szobahőmérsékleten inkubált talajokon vizsgáltuk.

\section{Az eredmények értékelése}

A korábbi vizsgálatok során felderített, jellemzően eltemetett humuszos rétegü foltokon gyüjtött minták részletes vizsgálati adatait mutatja be az 1. táblázat. A 
vizsgálatba a szántott rétegen és az eltemetett humuszos rétegen kívül a közvetlenül a szántott réteg alatti, általában kisebb humusztartalmú altalaj és az eltemetett rétegek alatti humuszmentes anyakőzet mintákat is bevontuk.

Az első pillanatban szembeötlik, hogy az eltemetett humuszos rétegek rétegközép mélység értéke a 11 mintavételi hely átlagában $131 \mathrm{~cm}$. Ezek a rétegek általában $30 \mathrm{~cm}$ vastagságúak, tehát a felső szélük átlagban $115 \mathrm{~cm}$ körül jelenik meg. Ez az átlag azonban nagy változékonyságot takar. A sekélyen, vagy közép mélyen (1. ábra) eltemetett humuszos rétegek viszonylag ritkán fordulnak elő, nagyobb kiterjedésben csak Vének körzetében találhatók, ahol emiatt már régebben meg is találták azokat. Gyakrabban fordulnak elő $150 \mathrm{~cm}$-nél mélyebben, ezért a szokásos talajszelvény feltárások során jelenlétük nem derül ki. Természetesen az ilyen mélységben megbúvó humuszos rétegek nem befolyásolják közvetlenül a növénytermesztés eredményeit, ökológiai szempontok miatt mégis hasznos lehet, ha ismerjük elhelyezkedésüket.

1. táblázat

A különböző talajrétegek fontosabb tulajdonságai $(\mathrm{n}=11)$

\begin{tabular}{|c|c|c|c|c|c|}
\hline $\begin{array}{l}\text { (1) } \\
\text { Tulajdonság és } \\
\text { mértékegysége }\end{array}$ & $\begin{array}{l}\text { (2) } \\
\text { Szántott } \\
\text { réteg }\end{array}$ & $\stackrel{(3)}{\text { Altalaj }}$ & $\begin{array}{l}\text { (4) } \\
\text { Eltemetett } \\
\text { humuszos } \\
\text { réteg }\end{array}$ & $\begin{array}{c}\text { (5) } \\
\text { Anya- } \\
\text { közet }\end{array}$ & $\begin{array}{c}(6) \\
\mathrm{SzD}_{5 \%}\end{array}$ \\
\hline $\begin{array}{l}\text { a) Átlagos rétegközép } \\
\text { mélység, cm } \\
\text { b) } \mathrm{K}_{\mathrm{A}} \\
\mathrm{pH}(\mathrm{KCl}) \\
\mathrm{CaCO}, \% \\
\text { c) } \mathrm{Humusz}, \% \\
\mathrm{NO}_{3}-\mathrm{N}, \mathrm{mg} / \mathrm{kg} \\
\mathrm{SO}_{4}^{2-}-\mathrm{S}, \mathrm{mg} / \mathrm{kg} \\
\mathrm{Na}, \mathrm{mg} / \mathrm{kg} \\
\mathrm{Mg}, \mathrm{mg} / \mathrm{kg} \\
\text { d) } \mathrm{AL}-\mathrm{P}_{2} \mathrm{O}_{5}, \mathrm{mg} / \mathrm{kg} \\
\text { e) } \mathrm{AL}-\mathrm{K}_{2} \mathrm{O}, \mathrm{mg} / \mathrm{kg}\end{array}$ & $\begin{array}{r}13,64 \\
46,00 \\
7,39 \\
23,09 \\
2,22 \\
23,22 \\
19,34 \\
157,64 \\
182,27 \\
320,36 \\
298,91\end{array}$ & $\begin{array}{r}53,45 \\
42,73 \\
7,63 \\
24,64 \\
0,95 \\
12,50 \\
22,78 \\
154,91 \\
208,45 \\
61,45 \\
196,00\end{array}$ & $\begin{array}{r}130,91 \\
49,09 \\
7,39 \\
13,79 \\
1,65 \\
10,03 \\
91,86 \\
160,36 \\
520,91 \\
59,64 \\
238,36\end{array}$ & $\begin{array}{r}181,45 \\
35,73 \\
7,71 \\
23,27 \\
0,55 \\
6,34 \\
49,70 \\
126,73 \\
330,45 \\
31,00 \\
150,18\end{array}$ & $\begin{array}{l}29,35^{* * * * *} \\
7,65^{* *} \\
0,15^{* * *} \\
6,96^{*} \\
0,53^{* * * *} \\
10,37 * \\
62,33 \text { n.s. } \\
48,72 \text { n.s. } \\
100,87^{* * * *} \\
82,48^{* * * *} \\
81,03^{* *}\end{array}$ \\
\hline $\begin{array}{l}\mathrm{Fe} \\
\mathrm{Al} \\
\mathrm{Zn} \\
\mathrm{Cu} \\
\mathrm{Mn} \\
\mathrm{Mo} \\
\mathrm{B} \\
\mathrm{Cd} \\
\mathrm{Cr} \\
\mathrm{Co} \\
\mathrm{Pb}\end{array}$ & $\begin{array}{r}K C l-E D \\
27,92 \\
3,57 \\
2,30 \\
3,28 \\
27,27 \\
0,028 \\
0,263 \\
0,066 \\
0,040 \\
0,123 \\
2,40\end{array}$ & $\begin{array}{r}\text { dható el } \\
17,52 \\
3,88 \\
0,46 \\
2,47 \\
14,66 \\
0,031 \\
0,068 \\
0,025 \\
0,040 \\
0,067 \\
1,60\end{array}$ & $\begin{array}{r}\text { rtalom, } m \\
84,60 \\
37,61 \\
0,46 \\
4,89 \\
46,26 \\
0,047 \\
0,054 \\
0,035 \\
0,059 \\
0,705 \\
3,12\end{array}$ & $\begin{array}{r}23,25 \\
5,95 \\
0,30 \\
1,32 \\
14,92 \\
0,025 \\
0,024 \\
0,020 \\
0,048 \\
0,149 \\
1,18\end{array}$ & $\begin{array}{l}33,84 * * \\
14,64 * * * * \\
0,87 * * * * \\
0,91 * * * * \\
15,95 * * * \\
0,016^{*} \\
0,073^{* * * *} \\
0,011^{* * * *} \\
0,016 \mathrm{n} . \mathrm{s} . \\
0,28 * * * \\
0,70 * * * *\end{array}$ \\
\hline
\end{tabular}

Megjegyzés: n. s.: nem szignifikáns; *: 5, **: 1,***: 0,1 és ****: 0,01\% szinten szignifikáns 


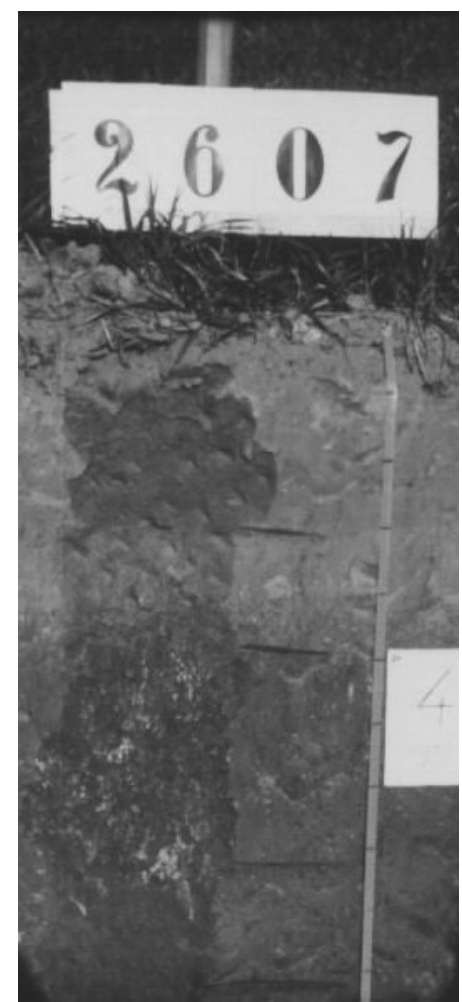

1. ábra

Közép mélyen eltemetett humuszos rétegü humuszos öntéstalaj Halászi mellett
$\mathrm{Az}$ eltemetett humuszos rétegek kötöttsége $\left(\mathrm{K}_{\mathrm{A}}\right)$ nem lényegesen nagyobb a felette lévő rétegeknél, ezért káros vízzáró, vagy gyökérfejlődést gátló hatásokkal nem kell számolnunk.

A mésztartalom és a $\mathrm{pH}$ némileg kisebb értéket mutat az eltemetett humuszos rétegekben. Ennek az lehet az oka, hogy ezek a rétegek eredetileg feltalaj korukban réti dinamika szerint fejlődtek, megindult bennük a kilúgozódási folyamat.

Átlagban az eltemetett humuszos rétegek humusztartalma nem nagyobb, mint a feltalajé. Ez részben lehet az utóbbi időszakok aerob viszonyainak hatására végbemenő lassú bomlás eredménye is. Néhány esetben találtunk a 3 $\mathrm{m}$ alatti rétegekben, jelenleg is állandó vízborítás alatt, 8-10\% szervesanyagtartalmú szurokfekete rétegeket is. Ezekben az esetekben az eredetileg lápos körülmények között kialakult mennyiség is lehetett nagy, ráadásul a vízborítás a bomlást gátolta.

$\mathrm{Az}$ eltemetett humuszos rétegek nagyobb Mg-, Fe-, Al-, Mn- és Cu-tartalma is a réti eredet következménye, összefügkisebb pH-értékkel. A makrotápanyagok gésbe hozható a levegőtlenséggel, vagy a kisebb pH-értekkel.
közül az oldható foszfortartalom kis mennyisége szembeötlö.

A mikroelemek közül az oldható réztartalom a réti dinamikával módosulva követi a szervesanyag-tartalmat, a Zn-tartalom viszont csak a szántott rétegben mutat az anyakőzethez képest nagyobb értéket. Ez azt bizonyítja, hogy a Zn-tartalom nem a biológiai felhalmozódás, hanem a légkörből való kiülepedés következtében növekedett meg. Ez a kiülepedés az eltemetett rétegek felszíni kialakulása során még nem volt a maihoz hasonló mértékü.

Az oldható Co- és a Pb-tartalom nagyobb az eltemetett rétegekben. Hasonló jelenséget EVSZEEV (1991) is megfigyelt eltemetett rétegekben, amit a nagyobb agyagtartalommal magyarázott.

Az általános talajvizsgálatból nem derül ki, de az inkubációs vizsgálat jól mutatja (2. táblázat), hogy az eltemetett humuszos réteg mikrobiológiailag inaktív, a 10 napos inkubáció alatt nitráttartalma gyakorlatilag nem változott. Ezzel ellentétben a karbonátos feltalajminták általában már mintavételkor is nagy nitráttartalmúak, és a nitrátmennyiség az inkubáció alatt tovább nő. 
2. táblázat

Az ásványi nitrogén tartalom alakulása talajminták inkubációja során

\begin{tabular}{|c|c|c|c|c|c|c|}
\hline \multirow{3}{*}{$\begin{array}{c}\text { (1) } \\
\text { Inkubálás } \\
\text { időtartama, } \\
\text { nap }\end{array}$} & \multicolumn{3}{|c|}{$\begin{array}{c}(2) \\
\text { Feltalaj }\end{array}$} & \multicolumn{3}{|c|}{$\begin{array}{c}\text { (3) } \\
\text { Eltemetett humuszos réteg }\end{array}$} \\
\hline & $\mathrm{NH}_{4}{ }^{+}-\mathrm{N}$ & $\mathrm{NO}_{3}^{-}-\mathrm{N}$ & $\mathrm{NO}_{2}^{-}-\mathrm{N}$ & $\mathrm{NH}_{4}{ }^{+}-\mathrm{N}$ & $\mathrm{NO}_{3}^{-}-\mathrm{N}$ & $\mathrm{NO}_{2}^{-}-\mathrm{N}$ \\
\hline & \multicolumn{6}{|c|}{$\mathrm{mg} / \mathrm{kg}$} \\
\hline 0 & 0,00 & 21,00 & 0,50 & 0,00 & 4,33 & 0,31 \\
\hline 1 & 0,43 & 34,67 & 3,78 & 2,13 & 5,67 & 0,65 \\
\hline 2 & 0,53 & 51,67 & 3,53 & 1,23 & 5,00 & 0,53 \\
\hline 3 & 1,27 & 46,50 & 1,84 & 1,40 & 5,33 & 0,25 \\
\hline 4 & 0,00 & 71,33 & 0,41 & 0,00 & 7,83 & 0,14 \\
\hline 5 & 0,00 & 63,33 & 0,39 & 0,00 & 5,67 & 0,21 \\
\hline 10 & 0,00 & 42,33 & 0,25 & 0,93 & 2,00 & 0,10 \\
\hline
\end{tabular}

$\mathrm{Az}$ eltemetett humuszos rétegek termékenységének tenyészedény-kísérletben történő vizsgálatához egy mosonmagyaróvári foltból, 80-100 cm-ről és egy bezenyei foltból (2. ábra), $220 \mathrm{~cm}$ alatti rétegből vettünk megfelelő mennyiségü mintát. Mint a 2. ábrán látható a bezenyei szelvényben $1 \mathrm{~m}$ körüli mélységben is volt egy eltemetett humuszos réteg, amit kis szervesanyag-tartalma miatt nem választhattunk.

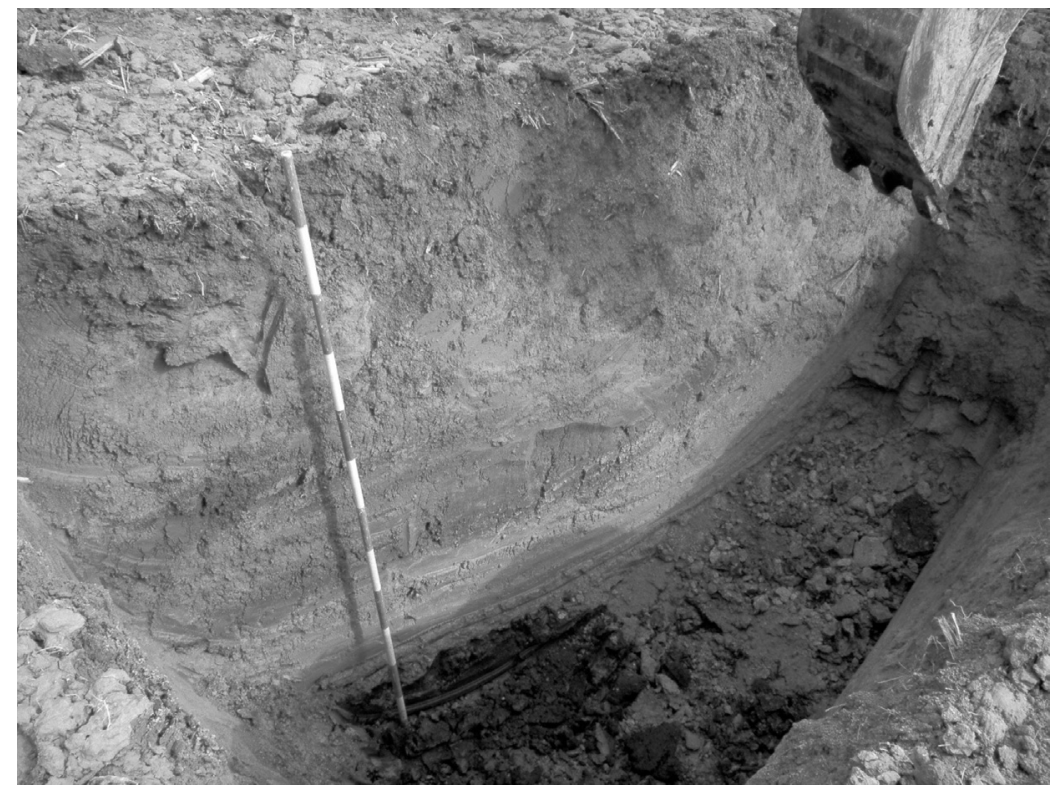

2. ábra

Eltemetett humuszos réteg Mosonmagyaróvár és Bezenye között

(a jelzőkaró osztásai $20 \mathrm{~cm}$-esek) 
Az első vetési sorozat (3. ábra) azt mutatta, hogy az eltemetett humuszos rétegekben az anyakőzethez hasonló eredményeket kaptunk, tehát gyakorlatilag nem tudtuk a növényeket felnevelni. Ezen a tényen a biológiai aktivitás segítése céljából $10 \%$ mennyiségben hozzákevert feltalaj sem tudott segíteni. NPK-mütrágya adagolása hatására ez, a vizsgálati adatok alapján foszforhiányból adódó probléma teljesen kiküszöbölödött és a hatás a további tenyészidőszakok során is megmaradt (3. táblázat). A mütrágyázott eltemetett humuszos rétegek termése nem volt szignifikánsan jobb, mint az ugyancsak mütrágyázott humuszmentes anyakőzeté.

A laboratóriumi analitikai és a tenyészedényes vizsgálatok eredményei alapján nem látunk okot arra, hogy az eltemetett humuszos rétegek kibányászására és hasznosítására javaslatot tegyünk. Úgy véljük, hogy ezek a rétegek még foltokban tör-

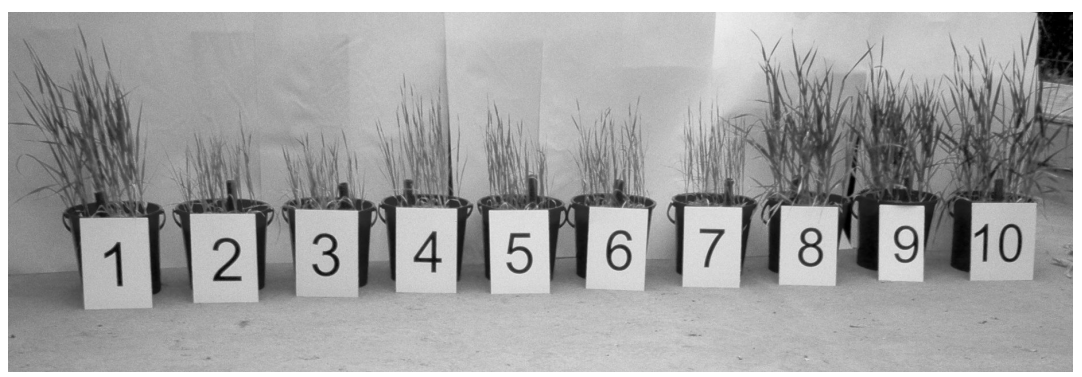

\section{3. ábra}

Tenyészedény-kísérlet tavaszi árpával. 1. Feltalaj. 2. Anyakőzet. 3. Eltemetett humuszos réteg (Mosonmagyaróvár, MO). 4. Eltemetett humuszos réteg (Bezenye, B). 5. Anyakőzet +

$10 \%$ feltalaj. 6. Eltemetett humuszos réteg $(\mathrm{MO})+10 \%$ feltalaj. 7. Eltemetett humuszos réteg $(\mathrm{B})+10 \%$ feltalaj. 8 . Anyakőzet + NPK-mütrágya. 9. Eltemetett humuszos réteg $(\mathrm{MO})$ + NPK-mütrágya. 10. Eltemetett humuszos réteg $(\mathrm{B})+\mathrm{NPK}$-mütrágya

\section{3. táblázat}

Növényi szárazanyag-termés (g/edény) eredmények a tenyészedény-kísérlet sorozat kezeléseiben

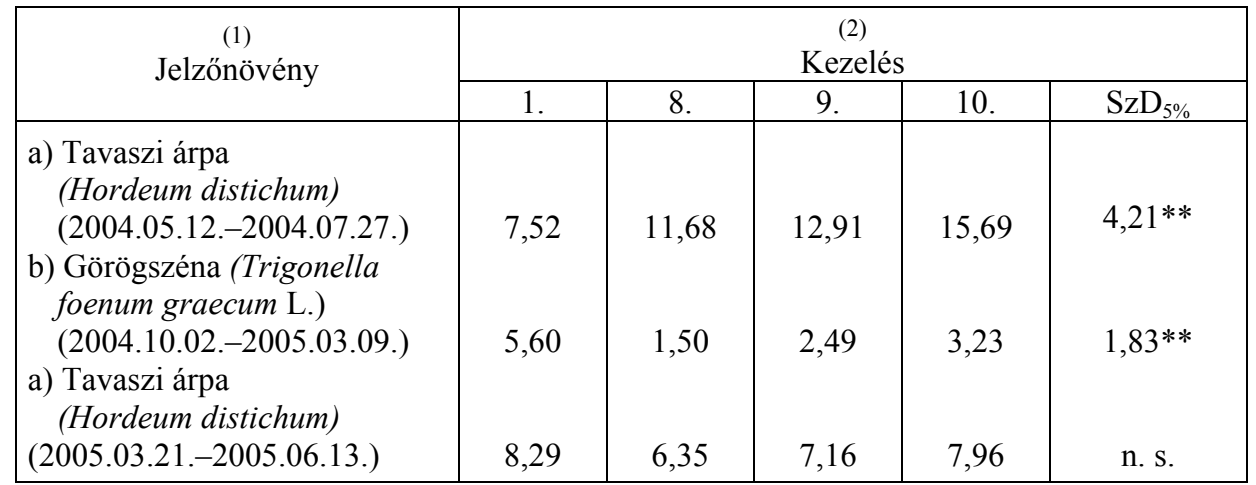

Megjegyzés: Árpa: 30 növ/edény, görögszéna: 7 növ/edény; Kezelés: lásd 3. ábra; n. s.: nem szignifikáns; **: $1 \%$ hibaszinten szignifikáns 
ténő megjelenésük ellenére is a jelenlegi elhelyezkedésükben hozzák a legtöbb hasznot az esetleges káros anyagok lefelé történő mozgásának korlátozásával egy olyan területen, ahol a felszín alatt maximális védelemre érdemes, jó minőségü édesvíz található.

Az eltemetett humuszos rétegek területi elterjedése tekintetében felszíni jelekre nem támaszkodhattunk. A jelenlegi sík felszín különböző pontjai alatt domborzati indikáció nélkül látszólag véletlenszerúen jelennek meg az eltemetett rétegek. Azért, hogy a kereséshez mégis valamilyen hipotézist felépíthessünk, a Mosonmagyaróvár és Dunaszentpál közötti, kb. 1000 feltárással viszonylag jobban jellemzett, 13373 ha területü térségre rögzítettük azokat a tulajdonságokat, amelyekről feltételeztük, hogy az eltemetett rétegek megjelenésével együtt járhatnak, vagy azok közelében megjelenhetnek.

Térinformatikai szoftver segítségével előállítottuk a felsorolt tulajdonságok foltjaitól, illetve vonalaitól mért, osztályozott távolságtérképeket („distance maps”) és megvizsgáltuk hogyan változik a különböző távolság-kategóriákban az eltemetett humuszos réteggel rendelkező talajfoltok részaránya (4. táblázat).

Megállapítottuk, hogy a kiválasztott területen az eltemetett humuszos rétegü foltok területi részaránya $24 \%$ körül van, ami lényegesen több mint azt korábban gondoltuk. Hasonló részarány várható a Szigetköz többi részén is, kivéve a FeketeerdőDunakiliti vonaltól nyugatra eső részt, ahol nagyon kevés ilyen folt várható.

A távolságtérképek adatai alapján megállapítottuk, hogy az eltemetett humuszos rétegü öntéstalajokat a Szigetközben nagyobb gyakorisággal és biztonsággal fogjuk megtalálni a vastag fedörétegü területeken, távol a felszín közeli kavicsos foltoktól, réti talajfoltok közelében, ahol az anyaközet szövete agyagos és nem feltétlenül a jelenlegi vízfolyások partjai mentén.

A vizsgálati helyeket a távolságtérképek adatainak figyelembe vételével besürítettük. Az eltemetett humuszos rétegü talajfoltok területi kiterjedését Thiessen poligonok képzésével határoztuk meg.

\section{4. táblázat}

Az eltemetett humuszos rétegü talajfoltok részaránya (\%) a vizsgált jellemzőktől mért távolság függvényében

\begin{tabular}{|l|c|c|c|c|c|}
\hline \multirow{2}{*}{\multicolumn{1}{|c|}{ Vizsgált tulajdonság }} & \multicolumn{5}{c|}{ (2) Távolság a vizsgált tulajdonságtól, m } \\
\cline { 2 - 6 } & 0 & $0-100$ & $100-500$ & $500-1000$ & $>1000$ \\
\hline a) Fedöréteg vastagság = 4-5 m & 56,86 & 36,74 & 31,12 & 25,10 & 18,86 \\
b) Az anyakőzet szövete = agyag & 41,16 & 21,54 & 18,24 & 15,34 & 16,25 \\
c) A szántott réteg szövete = & & & & & \\
$\quad$ homok & 19,37 & 21,11 & 21,55 & 23,75 & - \\
$\quad$ agyag & 18,82 & 23,33 & 21,86 & 24,21 & - \\
d) A talaj fö́típusa = Réti & - & 32,78 & 28,19 & 13,39 & 2,38 \\
e) Kavicsréteg felszín alatti mély- & & & & & \\
sége < 100 cm & 16,69 & 16,76 & 18,64 & 23,76 & 27,86 \\
f) Felszíni vízhálózat vonalai & - & 18,59 & 19,21 & 23,45 & 28,90 \\
\hline
\end{tabular}


A kialakított térkép (4. ábra) alapján a Szigetköz jelenlegi területén belül több hullámban félköríves jellegủ elrendeződést találunk. Ezzel egybevág PÉCSI (1962) megállapítása, hogy a Szigetközben a Dunának nincs völgye, hanem egy orsó alakú hordalékkúpja. Ezen belül a foltok aprók, nagyobb egybefüggő kiterjedéssel csak Vének környékén találkozunk.

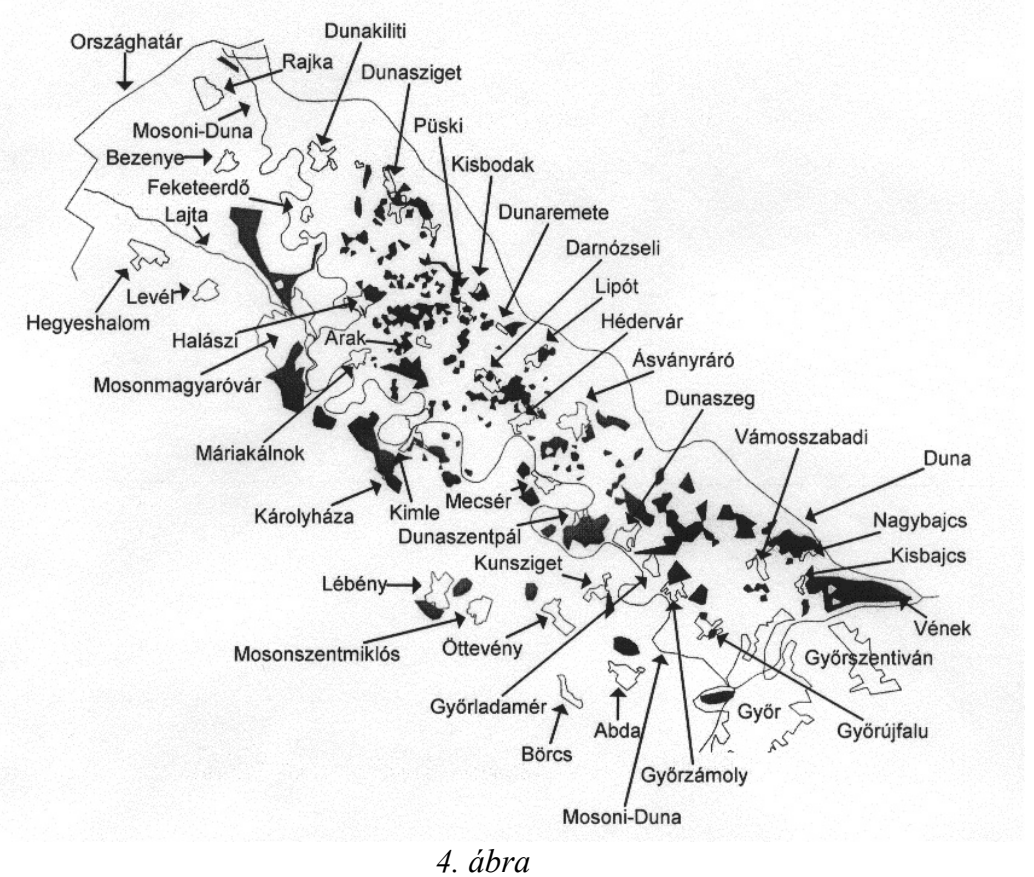

Az eltemetett humuszos réteg foltok elhelyezkedése a Szigetközben és környékén

Sok gondot jelentett a Mosoni-síkság vizsgálata, mert onnan nagyon kevés korábbi térképi anyagot találtunk. Az hamarosan világosan kiderült, hogy a nyugati részen, Bezenyétöl Mosonmagyaróvárig a Lajta hordaléksávja szab határt az eltemetett humuszos rétegek előfordulásának. Ezt a lehetőséget SZÁDECZKY-KARDOS (1937) vizsgálataiból is kikövetkeztethetjük, melyek szerint a Lajta folyó mai folyása a pleisztocén második felében teljesen kialakult, az általunk vizsgált rétegek viszont a holocénben keletkeztek.

Az eltemetett humuszos rétegek előfordulási sávja a Lajta Mosoni-Dunába történő betorkolása után is szorosan a Mosoni-Duna mellett marad, egészen Kimléig. Innen kezdve azonban sokáig kis sikerrel kerestük a folytatást.

Később kiderült, hogy ez a sáv Kimle és Öttevény között egy egészen Lébényig tartó, a Rábca hordaléksávjáig eljutó félkörívet ír le, hasonlóan ahhoz, ahogy ezzel szemben a Mosoni-Duna viszont visszahúzódik Mecsérig. Ebben a bezárt körben találjuk a vidék egyetlen nagyobb felszíni pleisztocén üledék foltját (MÁFI, 1956), amit később nem fedett be a holocén réteg. Ezt a pleisztocén foltot a kiöntések so- 
rán a Mosoni-Duna megkerülte, ezért az eltemetett rétegek nem Mecsérnél, hanem inkább Lébénynél vannak. Ez egybeesik RÓNAI (1960) vizsgálataival, amelyekben megállapítja, hogy a Mosoni-Duna magasabban folyik, mint a déli Kisalföld tengelyében a Rábca.

Két helyen radiokarbon kormeghatározást is végeztettünk az eltemetett humuszos rétegek anyagából. A vizsgálatokat az ATOMKI Környezetanalitikai Laboratóriuma végezte. Az egyik minta a tenyészedény-kísérletben is használt bezenyei szelvény $220-250 \mathrm{~cm}$ rétegéböl származik, a másik pedig a Szigetköz belsejéböl, Györzámoly határából, 210-230 cm mélységböl. A bezenyei mintára $1830 \pm 40$ év BP, a győrzámolyira pedig $3690 \pm 50$ év BP értékeket kaptunk. Valószínúleg találnánk foltokat, ahol ettől valamivel nagyobb kort állapítanánk meg. Úgy gondoljuk, hogy a legrégebbi eltemetett humuszos rétegek a Szigetközben és környékén 20005000 évvel ezelött keletkeztek. Kell lenni ettől sokkal későbbi képződményeknek is, hiszen mindkét vizsgált réteg felett volt még további eltemetett humuszos réteg, amelyek nyilván fiatalabbak.

\section{Összefoglalás}

Összegyűjtöttük a Szigetközre vonatkozó és az eltemetett rétegek kimutatását is lehetővé tevő talajfeltárások adatait és azokat szükség szerint további helyszíni vizsgálatokkal egészítettük ki. A használható korábbi feltárások helyei a Szigetközben egyenetlenül oszlanak el, a Mosoni-síkságon pedig majdnem teljesen hiányoznak, ezért ott különösen sok kiegészitő vizsgálatra volt szükség. Végül több mint 2000 talajszelvény $150 \mathrm{~cm}$ mélységig terjedő vizsgálatának adatsorait tekintettük át. A feltárások helyeinek koordinátáit digitális állományba rögzítettük. Saját feltárásaink helyeit GPS segítségével azonosítottuk, a más forrásból származó korábbi feltárások koordinátáit talajtérképek és topográfiai térképek egybevetésével határoztuk meg.

A digitalizált pontokból térinformatikai szoftver segítségével, Thiessen poligonok képzése útján állítottuk elő a folthatárokat.

Az eltemetett humuszos talajrétegek vizsgálata során megállapítottuk, hogy azok többnyire mélyen helyezkednek el, humusztartalmuk általában nem nagyobb, mint a feltalajé, foszforhiányosak, biológiailag inaktívak, oldható mikroelem-tartalmuk réti dinamikára utal. Környezetvédelmi szempontokat is figyelembe véve, jelenlegi helyzetükben hagyásukat tartjuk célszerünek.

Az elvégzett radiokarbon meghatározások alapján megállapítható, hogy az eltemetett rétegek keletkezése a különböző helyszíneken 3-4 ezer éves időtartamban történhetett.

A területi elterjedésre vonatkozóan megállapítottuk, hogy foltokban vannak ugyan, de összes területük a Szigetköz mintegy 20\%-át lefedi a korábbi 3-4\%-os becsléssel szemben. A Szigetköz belső területén az eltemetett humuszos rétegü foltok félköríves, vagy orsós elrendeződését véltük felfedezni. A Mosoni-síkságon Bezenyétöl Kimléig a Mosoni-Duna mentén alkotnak majdnem teljesen összefüggő 
sávot. Kimlétől Öttevényig ez a sáv félkörívben egészen Lébényig, a Rábca hordalékkúpjáig jut el, megkerülve a Mecsér alatt lévő nagy pleisztocén eredetű foltot.

Kulcsszavak: eltemetett talaj, tenyészedény-kísérlet, mikroelem, radiokarbon kor

A kutatást a T 037343 OTKA téma támogatásával végeztük.

\section{Irodalom}

BARANYI F. et al. (szerk.), 1987. Útmutató a nagyméretarányú országos talajtérképezés végrehajtásához. Melioráció-öntözés és tápanyaggazdálkodás. Agroinform. Budapest.

DufFy, C. C., McCallister, D. L. \& RenKen, R. R., 1997. Carbon tetrachloride retention by modern and buried soil A horizons. Journal of Environmental Quality. 26. $1123-1127$.

EvszeEv, A. V., 1991. O golocenovüh pogrebennüh pocsvah szevera zapadnoj szibiri i nacsal'nom étape pocsvoobrazovanija. Pocsvovedenie. (1) 19-27.

GeraszimOV, I. P., 1974. A paleotalajok természete és eredete. Agrokémia és Talajtan. 23. $1-10$

GöCSEI I., 1979. A Szigetköz természetföldrajza. Földrajzi Tanulmányok. 16. Akadémiai Kiadó. Budapest.

IMRE J., 1998. Termőföldünk. Mezögazdasági Szaktudás Kiadó. Budapest.

Izsó I. (szerk.), 1986. Táblázatok a termőföld értékeléséhez. MÉM Földügyi és Térképészeti Hivatal. Budapest.

MÁFI, 1956. Magyarország Földtani Térképe. Magyar Állami Földtani Intézet, Budapest.

MikLAY F. \& MolNÁR L., 1968. A Mosoni-síkság talajviszonyai. Agrokémia és Talajtan. 17. 495-506.

MTA TAKI, 1986. A Gabcsikovo-Nagymarosi Vízlépcsőrendszer várható talajtani hatásai. Kézirat. MTA TAKI. Budapest.

PÉCSI M., 1962. A Kisalföld geomorfológiai térképe. Földrajzi Közlemények. 10. 113140.

RÓNAI A., 1960. Vízföldtani tanulmány a Kisalföldröl. Hidrológiai Közlöny. 6. 470484.

SeVüReV, L. T. et al., 1988. Pogrebennüe pocsvü kalacsszkoj vozvüsennoszti. Pocsvovedenie. (4) 5-18.

Stefanovits P., 1943. Magyarázatok Magyarország Geológiai és Talajismereti Térképéhez. Bős, 1:25 000 Nr. 4859/1. Magyar Királyi Földtani Intézet Kiadása. Budapest. 1-58.

STEFANOVITS P. \& GÓCZÁN L., 1962. A Kisalföld magyarországi részének talajföldrajzi viszonyai. Földrajzi Közlemények. 10. 195-208.

SZABOLCS I. (szerk.), 1966. A genetikus üzemi térképezés módszerkönyve. OMMI. Budapest.

SZÁDECZKY-KARDOS E., 1937. A Lajta folyó kialakulásáról. Földrajzi Közlemények. 60. $27-31$. 
SzŰCS L., 1958. A Maros menti alluviumok talajföldrajzi törvényszerüségeinek feltárása Makó környékén. Agrokémia és Talajtan 7. 313-330.

SzÜCS M., 1984. Zárójelentés a GNV Szigetközre eső hatásterületén végzett talajvizsgálatokról 1983-1984-ben. Pannon Agrártudományi Egyetem Termelésfejlesztési Osztálya Mosonmagyaróvár és VIZITERV. Kézirat.

SzÜCS, M., 1996. GIS-based area scale simulation of the changes in ground water capillary rise for the Szigetkoz region of Hungary. In: XVIIIth Conference of the Danube countries, Graz, August 1996. Vol. 19/2. C-79-84.

SzÜCS, M., 1998. GIS based soil water mangement map for the Szigetköz region of Hungary. In: Proc. XIX ${ }^{\text {th }}$ Conference of the Danube Countries, Osijek 1998. 255260.

SzÜCS M. \& PALKOVITS G., 1987. Jelentés a Bős-Nagymarosi Vízlépcsőrendszer hatásterületén 1986-ban végzett talajvizsgálatokról. Pannon Agrártudományi Egyetem Termelésfejlesztési Osztálya Mosonmagyaróvár és VIZITERV. Kézirat.

SzŰCS M. \& SzŰCS M.-NÉ, 2000. Mikroelem-tartalmi változások vizsgálata szigetközi talajokban térinformatikai eszközök segítségével. In: IX. Térinformatika a felsőoktatásban Szimpózium, Budapest, 2000. október 18. 84-88. (CD-ROM).

ID. VÁRALLYAY GY., 1942. Magyarázatok Magyarország Geológiai és Talajismereti Térképéhez. Moson, 1:25000 Nr. 4858/4. Magyar Királyi Földtani Intézet Kiadása. Budapest. 1-58.

VÁRALLYAY GY., 1992. A Szigetköz és környékének talajviszonyai különös tekintettel azok vízgazdálkodására. Acta Ovariensis. 34. (1) 65-73.

Érkezett: 2006. május 18. 


\title{
Buried Humus Layers in the Szigetköz Region of Hungary
}

\author{
M. SZÜCS and L. SZÜCS \\ Department of Soil Science and Water Management, University of West Hungary, \\ Mosonmagyaróvár (Hungary)
}

\section{Summary}

Earlier investigations on soil profiles in the Szigetköz region of Hungary, suitable for the detection of buried layers, were used to collect data, which were supplemented where necessary with fresh on-site analyses. The sites of previous investigations suitable for this purpose were unevenly distributed over the Szigetköz region and very few were located on the Moson Plain, so a large number of additional analyses were required on this area. Data series from a total of over 2000 soil profiles, analysed to a depth of $150 \mathrm{~cm}$, were finally available. The coordinates of the sampling locations were digitalized, using GPS data to identify the sites of fresh analyses, and the comparison of soil maps and topographical maps to establish the coordinates of earlier investigations.

GIS software based on the formation of Thiessen polygons was used to map the spot boundaries.

The analysis showed that buried humus layers were generally found at a considerable depth. Their humus content was generally no greater than that of the topsoil, they were deficient in phosphorus and biologically inactive, while their soluble trace element content was indicative of meadow soil-forming processes. A consideration of environment protection aspects suggests that these buried humus layers should be left intact in their present position.

Radiocarbon dating revealed that the buried layers found at various locations were formed over a period of 3-4 thousand years.

Although these layers are found in spots, their total area is now estimated to be approximately $20 \%$ of the whole Szigetköz region, compared with previous estimates of $3-4 \%$. In the central part of the region the buried spots appear to be arranged in a semicircular or spindle-like form, while on the Moson Plain they form an almost continuous band along the Moson Branch of the Danube, from Bezenye to Kimle. Between Kimle and Öttevény this band veers round in a semicircle, circumventing the large Pleistocene spot near the village of Mecsér and reaching the alluvial cone of the River Rábca at Lébény.

Table 1. Major properties of the various soil layers, $n=11$. (1) Property and units. a) Mean depth of the centre of the layer, $\mathrm{cm}$; b) Upper limit of plasticity according to Arany; c) Humus, \%; d) Ammonium lactate-soluble $\mathrm{P}_{2} \mathrm{O}_{5}, \mathrm{mg} / \mathrm{kg}$; e) Ammonium lactate-soluble $\mathrm{K}_{2} \mathrm{O}, \mathrm{mg} / \mathrm{kg}$. (2) Ploughed layer. (3) Subsoil. (4) Buried humus layer. (5) Parent material. (6) $\mathrm{LSD}_{5 \%}$. A. KCl-EDTA-soluble element content, $\mathrm{mg} / \mathrm{kg}$. Note: n.s.: non-significant; significant at the $* 5 \%, * * 1 \%, * * * 0.1 \%$ and $* * * * 0.01 \%$ level of probability, respectively.

Table 2. Changes in mineral nitrogen content during the incubation of soil samples. (1) Incubation period, days. (2) Topsoil. (3) Buried humus layer. 
Table 3. Plant dry matter yields (g/pot) in the various treatments of the pot experiment. (1) Indicator plant. a) Spring barley; b) Fenugreek. (2) Treatments: see Figure 3. Note: Barley: 30 plants/pot, fenugreek: 7 plants/pot. n.s.: non-significant; $* *$ : significant at the $1 \%$ level of probability.

Table 4. Ratio (\%) of soil spots with buried humus layers as a function of the distance from various features. (1) Feature. a) Thickness of covering layer $=4-5 \mathrm{~m}$; b) Texture of the parent material = clay; c) Texture of the ploughed layer = sand or clay; d) Main soil type = Meadow; e) Depth of the gravel layer below the surface $<100 \mathrm{~cm}$; f) Outline of surface water network. (2) Distance from the relevant feature, $\mathrm{m}$.

Fig. 1. Humus-rich alluvial soil with a buried humus layer at a moderate depth, near the village of Halászi.

Fig. 2. Buried humus layer between Mosonmagyaróvár and Bezenye (gradations indicate $20 \mathrm{~cm}$ intervals).

Fig. 3. Pot experiment with spring barley as indicator plant. 1. Topsoil. 2. Parent material. 3. Buried humus layer (Mosonmagyaróvár, MO). 4. Buried humus layer (Bezenye, B). 5. Parent material $+10 \%$ topsoil. 6. Buried humus layer $(\mathrm{MO})+10 \%$ topsoil. 7. Buried humus layer $(\mathrm{B})+10 \%$ topsoil. 8. Parent material + NPK mineral fertilizer. 9. Buried humus layer (MO) + NPK mineral fertilizer. 10. Buried humus layer (B) + NPK mineral fertilizer.

Fig. 4. Location of spots with buried humus layers in and around the Szigetköz region. 